表 $\quad 1$

$\mathrm{Al}(15.2 \mathrm{~mol} \%)-\mathrm{Fe}(84.8 \mathrm{~mol} \%)$ 合金上の被膜, 酸䇣

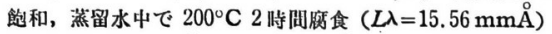

\begin{tabular}{|c|c|c|c|c|}
\hline$r(\mathrm{~mm})$ & $\begin{array}{c}d_{h k l}(\stackrel{(}{(}) \\
\text { 笑測 值 }\end{array}$ & $\begin{array}{l}d_{h k l}(\AA) \\
\text { 計 }(\AA) \\
\text { 算 值 }\end{array}$ & $(h k l)$ & 物 留 \\
\hline 3.44 & 4.53 & 4.53 & (001)? & $\mathrm{FeOOH}^{*}$ \\
\hline 5.89 & 2.65 & 2.65 & (100) & $\mathrm{FeOOH}^{*}$ \\
\hline 10.20 & 1.53 & 1.53 & (110) & $\mathrm{FeOOH}^{*}$ \\
\hline 6.25 & 2.50 & 2. 506 & (311) & $\gamma-\mathrm{Fe}_{2} \mathrm{O}_{3}$ \\
\hline 10.40 & 1.502 & - & - & ? \\
\hline
\end{tabular}

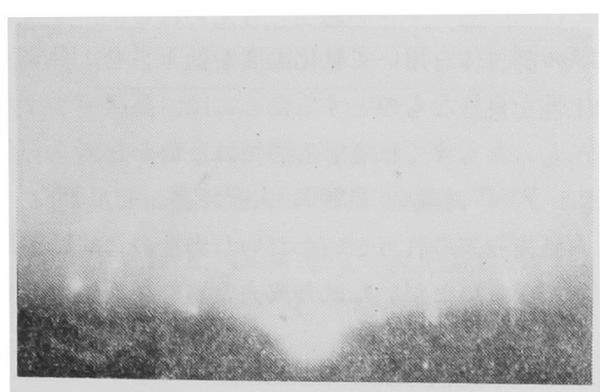

写真 $3 \mathrm{Fe}-\mathrm{Al}$ 合金表面の反射回折図

これを $\mathrm{Fe}(\mathrm{OH})_{2}{ }^{5}{ }^{5}$ と比較してみると，表 2 の結果となる。す
なわち, $\mathrm{Fe}(\mathrm{OH})_{2}$ の方が多少大さい

単位胞を有することになる。これは

Feitknecht ${ }^{6)}$ の考党によれば， $\mathrm{OH}^{-}$

イオンが $\mathrm{O}^{2-}$ イオンにより置換さ

表 2

$\begin{array}{lcc} & a_{0} & c_{0} \\ \mathrm{Fe}(\mathrm{OH})_{2} & 3.24 & 4.47 \\ \mathrm{FeOOH} & 3.06 & \text { ? }\end{array}$

れるため, $\mathrm{Fe}(\mathrm{OH})_{2}$ より $\mathrm{FeOOH}^{*}$ の方が小さい単位胞をもつと

いうことである。

また，写真 2 の回折図を見れば, 回折環が伟心側で sharp に切 れているが, 外側に向っては diffuse である。この回折環の特徽 は stacking fault といわれ, 層構造をもつ物質からのデハィイーシ ェラー図に非常にしばしば認められるものである。金䖺の水酸化

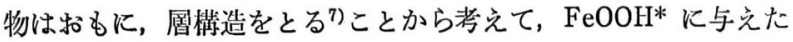
槛造が妥当なるのと思われる。

終りに, この研究の発表を許可された秋葉武定理事長, ならび に研究の御指導を戴きました東大工学部向坊隆教授就よび中土晃 所長に厚く感謝致しますั。

5) R.W.G. Wyckoff, Crystal Structure Vol. I. (1957).

6) W. Feitknecht, Z. Elektrochem. 63, 34 (1959).

7) Z. G. Pinsker, Electron Diffraction p. 266 (1953).

\title{
テトラクロルアルカンよりアジピン酸, コルク酸の合成
}

（昭和 36 年 11 月 13 日受理）

平尾一郎・藤本 勉・鬼塚朋考・丸山 実*

\section{1 緒言}

エチレンと四塩化炭素とのテロメリゼーションにより $\alpha, \alpha, \alpha$, $\omega$-テトラクロルアルカンが得られる1,2)。生成する $\alpha, \alpha, \alpha, \omega$-テ トラクロルアルカンの組成は反応条件により異なるが，加殴下に おいては著者らの研究に和いても 1,1,1,5-テトラクロルペンタ ンは 60〜70 wt \%, 1,1,1,7-テトラクロルヘプタンは 15〜20 wt \%程度である。本報ではエチンンと四塩化炭素とのテロメリゼー ションにより得られた 1,1,1,5-テトラクロルペンタン拈び 1 , 1,1,7-テトラクロルヘプタンよりシアノ化，加水成解を行なって アジピン酸和よ゙゙ンルク酸を合成した。

$$
\begin{aligned}
& n \mathrm{C}_{2} \mathrm{H}_{4}+\mathrm{CCl}_{4} \longrightarrow \mathrm{CCl}_{3}\left(\mathrm{CH}_{2} \mathrm{CH}_{2}\right)_{n} \mathrm{Cl} \\
& \mathrm{CCl}_{3}\left(\mathrm{CH}_{2} \mathrm{CH}_{2}\right)_{n} \mathrm{Cl} \stackrel{\mathrm{NaCN}}{\longrightarrow} \mathrm{CCl}_{3}\left(\mathrm{CH}_{2} \mathrm{CH}_{2}\right)_{n} \mathrm{CN} \\
& \mathrm{CCl}_{3}\left(\mathrm{CH}_{2} \mathrm{CH}_{2}\right)_{n} \mathrm{CN} \stackrel{\mathrm{H}_{2} \mathrm{O}}{\longrightarrow} \mathrm{HOOC}\left(\mathrm{CH}_{2} \mathrm{CH}_{2}\right)_{n} \mathrm{COOH} \\
& \quad(n=2 ; \text { アシピ酸, } n=3 ; \text { 『ル酸 })
\end{aligned}
$$

\section{2 実験および結果}

$\alpha, \alpha, \alpha, \omega$-テトラクロルアルカンは, アゾビスイソブチロニト リルを開始剂として, 加圧下でェチレンと四塩化炭素とのテロメ リゼーションKよって合成し，1,1,1,5-テトラクロルペンタン (bp 112 113ㄷ/24 mmHg) 拈よび 1,1,1,7-テトラクロルヘプタ ン（bp 142 $144^{\circ} \mathrm{C} / 24 \mathrm{mmHg}$ ）はテロマーを分留して得た。

* 九州工業大学 : 戸畑市中原.

1) M.S. Kharasch, E.V. Jensen, W. H. Urry, J. Am. Chem. Soc. 69, 1100 (1947).

2) R. M. Joyce, W.E. Hanford, J. Harmon, ibid. 70, 2529, (1948).

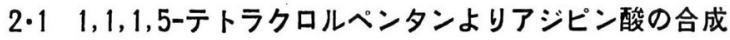

2・1・1 1,1,1-トリクロル-5-シアノペンタンの合成 シアン化 ナトyウム $17 \mathrm{~g}$ を水 $18 \mathrm{~m} l$ に溶解させた溶液に $1,1,1,5$-テト, ラクロルペンタン $52.5 \mathrm{~g}$ を 2-メトキシエタノール $90 \mathrm{ml}$ に溶 解して加完，かきまぜながら 97 98 C に 4 時間保った。冷却後 口過し, 口液を減圧蒸留して 1,1,1-トリクロル-5-シアノペンタ ン (bp 121〜 $124^{\circ} \mathrm{C} / 7 \mathrm{mmHg}$ ) を $41.9 \mathrm{~g}$ (収率 $84 \%$ ) 得た。

元素分析 $\left(\mathrm{NC}\left(\mathrm{CH}_{2} \mathrm{CH}_{2}\right)_{2} \mathrm{CCl}_{3}\right.$ として $)$

計算値 $\mathrm{N}=6.98 \%$ 分析値 $\mathrm{N}=6.86 \%$

2・1·2 1,1,1-トリクロル-5-シアノペンタンの加水分解による アジピン酸の合成 1,1,1-トリクロル-5-シアノペンタン $20 \mathrm{~g}$ に かきまぜながら 93\% 硫酸 $20 \mathrm{~g}$ を加兄て，90 95 ${ }^{\circ} \mathrm{C}$ に 10 分間 保ったのち，更に $65 \%$ 硫酸 $22.8 \mathrm{~g}$ を 20 分か外て㵜下した。 滴下後 $110 \sim 120^{\circ} \mathrm{C}$ で 3 時間かきまぜた。反応後冷却し, 反応混 合物を 2 倍量の水水中に注いで, 析出する粗アジピン酸をけ取し

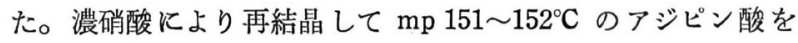
$11.3 \mathrm{~g}$ (収率 $77.4 \%$ ) を得た。

元素分析 $\left(\mathrm{HOOC}\left(\mathrm{CH}_{2} \mathrm{CH}_{2}\right)_{2} \mathrm{COOH}\right.$ として $)$

$$
\begin{array}{llll}
\text { 計 算 值 } & \mathrm{C}=49.32 \% & \mathrm{H}=6.85 \% \\
\text { 分 析 值 } & \mathrm{C}=48.96 \% & \mathrm{H}=6.85 \%
\end{array}
$$

$2 \cdot 2$ 1,1,1,7-テトラクロルヘプタンよりコルク酸の合成

2·2・1 1,1,1-トリクロル-7-シアノヘプタンの合成 シアン化 ナトリウム $34 \mathrm{~g}$ を水 $36 \mathrm{~m} l$ に溶解した溶液をかきまぜながら $50^{\circ} \mathrm{C}$ に保ち，1,1,1,7-テトラクロルヘプタン $119 \mathrm{~g}$ を2-メト キシェタノール $180 \mathrm{~m} l$ に溶解した溶液を滴下した。滴下後 97 $\sim 98^{\circ} \mathrm{C}$ で 5 時間かきまぜた。冷却後口過し, 口液を減圧蒸留して 
1,1,1-トリクロル-7-シアノヘプタン（bp 138〜 $139^{\circ} \mathrm{C} / 7 \mathrm{mmHg}$ ) を $100 \mathrm{~g}$ (收率 $88.6 \%$ ) 得た。

元素分析 $\left(\mathrm{NC}\left(\mathrm{CH}_{2} \mathrm{CH}_{2}\right)_{3} \mathrm{CCl}_{3}\right.$ として $)$

計算值 $\mathrm{N}=6.12 \%$ 分析值 $\mathrm{N}=6.11 \%$

2・2・2 1,1,1-トリクロル-7-シアノヘプタンの加水分解による

コルク酸の合成 $1,1,1-$ トリクロル-7-シアノープタン $22.9 \mathrm{~g}$ K

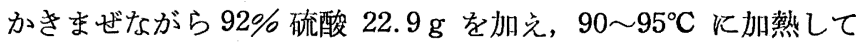

10 分間かきまぜたのち, 更に $72 \%$ 硫酸 $18.8 \mathrm{~g}$ を滴下した。滴 下後 $110 \sim 120^{\circ} \mathrm{C}$ で 3 時間かきぜたのち冷却し， 2 倍量の水水 中に注いで析出したコルク酸を口取した。水から再結晶して mp $139 \sim 140^{\circ} \mathrm{C}$ のコルク酸を $8.9 \mathrm{~g}$ (収率 $51 \%$ ) 得た。

元素分析 $\left(\mathrm{HOOC}\left(\mathrm{CH}_{2} \mathrm{CH}_{2}\right)_{3} \mathrm{COOH}\right.$ として)

$$
\text { 計 算 值 } \mathrm{C}=55.17 \% \mathrm{H}=8.05 \%
$$$$
\text { 分 析 值 } \mathrm{C}=55.15 \% \mathrm{H}=8.09 \%
$$

\title{
クエン酸発酵菌の保存と生酸能の变化
}

\author{
(昭和 37 年 1 月 17 日受理)
}

宇佐美 昭次・武 富 昇 ${ }^{*}$

\section{1 緒言}

いずれの発醅に括いても菌の発酵力の維持は重要な問題であ る。保存中に変化を受け難い発酵菌もあるが，黑カビとくにクェ ン酸生産菌は比較的変化を受け易い上5で，一般に成熟した胞子 を菌糸より離して貯学ると比㬵的退化が防げるといわれている。

著者らは既に本邦各地の土壤から耐酸性黒カビを数多く分離 し, 液内培養法によるクエン酸生産能を試験した結果を報告した が1)，本報はその らちの 1 菌株について，多くの天然物を保存培 地として使用し, 保存中の生酸能変化を検討した結果について述 べる。

\section{2 実験および考察}

\section{$2 \cdot 1$ 実 験 方 法}

使用菌は Asp. niger WU-2078 菌。本菌をまず合成培地寒天 (ショ糖〜硝酸アンモニウム系で亜鉛を微量加えたもの 2) ) で 30 ${ }^{\circ} \mathrm{C}, 10$ 日間培養する。着生した胞子をあらかじめ加圧減菌した 保存培地飞接種する。5 7 日間, $30^{\circ} \mathrm{C}$ で培養後, 真空デシケー ター中で乾燥し, 容器 (硬質試験管)を溶封して保存した。保存中 の温度は室温（温度变化を少なくするため地下室に置いた。冬期 $5 \sim 10^{\circ} \mathrm{C}$, 夏期 $\left.15 \sim 25^{\circ} \mathrm{C}\right)$ 拈よび冷蔵庫 $\left(0 \sim 5^{\circ} \mathrm{C}\right)$ の二通りにつ いて行なった。生酸能試験は, まず保存菌の入っている試験管を 開封して, 既報のよ $5 k^{22}$ 合成培地寒天で 7 日間培養後, 着生胞 子を $30^{\circ} \mathrm{C} て ゙ 11$ 日間振とう培養した。生酸能試験に使用した培 地組成は次のと和りである。

Sucrose $140 \mathrm{~g}, \quad \mathrm{NH}_{4} \mathrm{NO}_{3} 2 \mathrm{~g}, \quad \mathrm{KH}_{2} \mathrm{PO}_{4} 2 \mathrm{~g}, \quad \mathrm{MgSO}_{4} \cdot 7 \mathrm{H}_{2} \mathrm{O}$ $0.25 \mathrm{~g}, \mathrm{MnSO}_{4} \cdot 4 \mathrm{H}_{2} \mathrm{O} 0.02 \mathrm{~g}, \mathrm{FeCl}_{3} \cdot 6 \mathrm{H}_{2} \mathrm{O} 0.02 \mathrm{~g}$, 麦芽计 20 $\mathrm{m} l, 1 \mathrm{~N}-\mathrm{HCl} 8 \mathrm{~m} l$

これを $1 l$ に定容する (pH 2.6)

\section{$2 \cdot 2$ 実験結果之考察}

本菌 (Asp. niger WU-2078) の分離時の生酸能（発䤃液の規

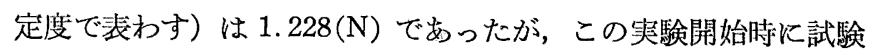
した結果では, 1.078(N) となっていた。一定期間保存後, 生酸 能試験をした結果を表 1 亿まとめて示した。

保存培地の種類によって生酸能維持効果が著しく異なり, 最も

* 早稲田大学理工学部応用化学科: 東京都新宿区戸塚町.

1）宇佐美, 佐川, 武富, 工化 62, 1027 (1959).

2）宇佐美, 武富, 工化 61,1494 (1958).
表 1 保存条件 と生酸能変化

\begin{tabular}{|c|c|c|c|c|c|c|c|}
\hline \multicolumn{2}{|c|}{ 保存条件 } & \multicolumn{6}{|c|}{ 保存期間（月）と生酸能 (N) } \\
\hline 培地 & 㴜 度 & 5 & 7 & 12 & 18 & 24 & 36 \\
\hline \pm 識 & 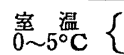 & $\begin{array}{l}1.034 \\
1.067\end{array}$ & $\begin{array}{l}1.008 \\
1.006\end{array}$ & $\begin{array}{l}0.892 \\
0.886\end{array}$ & $\begin{array}{l}0.910 \\
0.925\end{array}$ & $\begin{array}{l}0.844 \\
0.864\end{array}$ & $\begin{array}{l}0.799 \\
0.862\end{array}$ \\
\hline 砂 & 堙 $5^{\circ{ }^{\circ} \mathrm{C}}$ & $\begin{array}{l}1.014 \\
1.002\end{array}$ & $\begin{array}{l}0.914 \\
1.026\end{array}$ & $\begin{array}{l}0.934 \\
0.822\end{array}$ & $\begin{array}{l}0.833 \\
0.820\end{array}$ & $\begin{array}{l}0.794 \\
0.783\end{array}$ & $\begin{array}{l}0.736 \\
0.769\end{array}$ \\
\hline $\begin{array}{l}\text { 5イ⿱ } \\
\text { ウ土 }\end{array}$ & 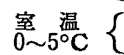 & $\begin{array}{l}0.822 \\
0.857\end{array}$ & $\begin{array}{l}0.715 \\
0.787\end{array}$ & $\begin{array}{l}0.614 \\
0.691\end{array}$ & $\begin{array}{l}0.509 \\
0.625\end{array}$ & $\begin{array}{l}0.356 \\
0.538\end{array}$ & $\begin{array}{l}0.334 \\
0.481\end{array}$ \\
\hline 口紙 & $\begin{array}{l}\text { 室漫 } \\
0 \sim 5^{\circ} \mathrm{C}\end{array}$ & $\begin{array}{l}0.956 \\
1.008\end{array}$ & $\begin{array}{l}0.824 \\
0.811\end{array}$ & $\begin{array}{l}0.859 \\
0.781\end{array}$ & $\begin{array}{l}0.722 \\
0.792\end{array}$ & $\begin{array}{l}0.732 \\
0.827\end{array}$ & $\begin{array}{l}0.570 \\
0.531\end{array}$ \\
\hline 竹 片 & $\begin{array}{l}\text { 容䕕 } \\
0 \sim 5^{\circ} \mathrm{C}\end{array}$ & $\begin{array}{l}0: 866 \\
0.844\end{array}$ & $\begin{array}{l}0.822 \\
0.899\end{array}$ & $\begin{array}{l}0.789 \\
0.695\end{array}$ & $\begin{array}{l}0.695 \\
0.573\end{array}$ & $\begin{array}{l}0.585 \\
0.568\end{array}$ & $\begin{array}{l}0.460 \\
0.548\end{array}$ \\
\hline 飯 & $\begin{array}{l}\text { 聜䕕 } \\
0 \sim 5^{\circ} \mathrm{C}\end{array}$ & $\begin{array}{l}0.903 \\
0.903\end{array}$ & $\begin{array}{l}0.582 \\
0.866\end{array}$ & $\begin{array}{l}0.461 \\
0.691\end{array}$ & $\begin{array}{l}0.323 \\
0.623\end{array}$ & 二 & $=$ \\
\hline 生甘藉 & 室 0 温 & $\begin{array}{l}0.684 \\
0.789\end{array}$ & $\begin{array}{l}0.691 \\
0.899\end{array}$ & $\begin{array}{l}0.557 \\
0.846\end{array}$ & $\begin{array}{l}0.411 \\
0.575\end{array}$ & 0.300 & - \\
\hline 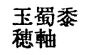 & $\begin{array}{l}\text { 室温 } \\
0 \sim 5^{\circ} \mathrm{C}\end{array}$ & $\begin{array}{l}0.892 \\
0.903\end{array}$ & $\begin{array}{l}0.811 \\
0.899\end{array}$ & $\begin{array}{l}0.560 \\
0.838\end{array}$ & $\begin{array}{l}0.481 \\
0.853\end{array}$ & $\begin{array}{l}0.343 \\
0.492\end{array}$ & E \\
\hline 票波。 & $\begin{array}{l}\text { 室 } \\
0 \sim 5^{\circ} \mathrm{C}\end{array}$ & $\begin{array}{l}0.899 \\
0.827\end{array}$ & $\begin{array}{l}0.969 \\
0.857\end{array}$ & $\begin{array}{l}0.684 \\
0.647\end{array}$ & $\begin{array}{l}0.425 \\
0.625\end{array}$ & $=$ & - \\
\hline パン & $\begin{array}{l}\text { 室渦 } \\
0 \sim 5^{\circ} \mathrm{C}\end{array}$ & $\begin{array}{l}0.680 \\
0.899\end{array}$ & $\begin{array}{l}0.638 \\
0.833\end{array}$ & $\begin{array}{l}0.575 \\
0.505\end{array}$ & $\begin{array}{l}0.468 \\
0.472\end{array}$ & $\begin{array}{l}0.300 \\
0.426\end{array}$ & $\begin{array}{l}0.306 \\
0.377\end{array}$ \\
\hline (胞子) & $\begin{array}{l}\text { 室 } \\
0 \sim 5^{\circ} \mathrm{C} \\
\end{array}$ & $\begin{array}{l}1.010 \\
1.008\end{array}$ & $\begin{array}{l}0.827 \\
0.923\end{array}$ & $\begin{array}{l}0.857 \\
0.899\end{array}$ & $\begin{array}{l}0.822 \\
0.805\end{array}$ & $\begin{array}{l}0.679 \\
0.638\end{array}$ & $\begin{array}{l}0.478 \\
0.520\end{array}$ \\
\hline
\end{tabular}

よく生酸能を保持することができたのは土壤で，保存中の生酸能 低下は 18 カ月後で 14〜15\%，36 カ月後で 20～25\% にとどま った。ついで砂，乾胞子（培地を使用せず，胞子を菌糸より離し て貯える)，口紙（合成培地を口紙にしみ込ませたもの）の順で他 の培地では 18 カ月経過後にはいずれも保存開始時の生酸能の 50\% 以下に低下し，更に保存を続けると形態的にす気菌系を生 ずるようになり遂には死滅した。

保存中に生酸能の著しい低下，拉よび死隇をみたものは括括む ね栄養源が豊富で, かつ湿潤状態㯰かれたものに多い。保存温 度の影響は比較的少ないが，湿潤状態の培地たとえば米飯などで は温度が高いと生酸能低下る著しくなるようである。な打生酸能 の低下した胞子でも生成酸中のクェン酸含量は保存開始前と変わ らず, 97〜98\% で，シュウ酸やグルコン酸を併生するようなこ とはなかった。

付記 : 著者らは生酸能試験に 先立って行なら胞子の前培養に は，合成培地飞微量の銅または亜鉛の硫酸塩を加えたるのを用い ると生酸能を強化し, 数カ月にわたって高い生酸能を維持するこ とができることを報告したが2)，これを保存培地として室温で 12 カ月保存すると,生酸能初期の $50 \%$ 以下に減少し, 18 力月後に は死減していた。またこの場合, 合成培地の糖濃度は実験した範 团(3〜12\%)では高い濃度の方が生酸能維持効果は良好であった。 